\title{
In vitro and in vivo toxicity of coal fly Ash Lechate
}

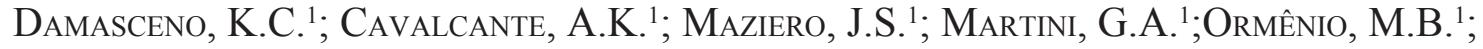 \\ Mamede, F.C. ${ }^{1}$; Miranda, C.S. ${ }^{1}$;CAmpello, F.A. ${ }^{1}$;Izidoro, J.C. ${ }^{1}$;Rogero, S.O. ${ }^{1}$; \\ Fungaro, D.A. ${ }^{1}$; Lopes-Ferreira, M. ${ }^{2} \&$ Rogero, J.R. ${ }^{1}$.

\footnotetext{
${ }^{1}$ Instituto de Pesquisas Energéticas e Nucleares, Centro de Química e Meio Ambiente, Universidade de São Paulo - USP, Brasil. ${ }^{2}$ Instituto Butantan,Laboratório Especial de Toxinologia Aplicada (LETA), São Paulo, São Paulo, Brasil.
}

Received February 01, 2018; Accept December 19, 2018

\begin{abstract}
Coal Fly ash is a major solid waste from coal-fired power stations. In Brazil, more than 4 million tons per year of fly ash are generated and only $30 \%$ is applied as raw material for cement and concrete production. The remaining is disposed in on-site ponds, nearby abandoned or active mine sites and landfills. The inadequate disposal of fly ash may pose a significant risk to the environment due to the possible leaching of hazardous pollutants into the surrounding soil and groundwater. A combination of leaching tests, cytotoxicity and ecotoxicological assays were used in this studyin order toevaluate the possible adverse effects of coal fly ash in non-target organisms. The sample was collected from coal-fired power plant located in Southern Brazil and the coal fly ash was submitted to a leaching procedure using USEPA SW 864 Method 1311. The leachate was prepared in six dilutions: $1.56 \%, 3.12 \%, 6.25 \%, 12.5 \%, 25 \%$ and $50 \%$. Acute toxicity tests were performed on NCTC clone 929 (CCIAL-020) culture cells by neutral red uptake cytotoxicity method; acute ecotoxicity usingDaphnia similisand Danio rerio embryos according to ABNT NBR 12713 and OECD 236, respectively were employed. The cytotoxicity index $\left(\mathrm{CI}_{50}\right)$ obtained was $33 \%$; the $\mathrm{EC}_{50}$ of D. similis after $48 \mathrm{~h}$ of exposure to the leachate was $7.25 \%$ and the $\mathrm{LC}_{50}$ of D. rerio after $96 \mathrm{~h}$ of exposure was $4.39 \%$. The results of these bioassays indicated toxicity of the coal fly ash leachate toward exposed organisms.
\end{abstract}

Keywords:Ecotoxicity; Coal Combustion Products; eluates; Daphnia similis; Danio rerio

\section{INTRODUCTION}

In Brazil, the main application of coal fly ash is at manufacture of cement and concrete ( $\sim 30 \%$ of total production). It is also used in small quantities as a road-bed stabilizer and in asphalt mixture. The remaining waste is disposed in on-site ponds, nearby abandoned or active mine sites or landfills (Fungaro et al., 2013).Fly ash production leads to the problem of disposal as well as environmental damage by causing soil and water pollution by leaching of pollutants. The leachability of the potentially toxic pollutants from the based fly ash products is also of particular importance. Thus, fly ash safe disposal and utilization is an important concern to safeguard the cleaner environment (Munawer, 2018).
Previous studies showed that fly ash from Brazilian coalfired power plants contain high concentrations of important trace elements such as arsenic, boron, chromium, copper, zinc, vanadium, nickel, among many others (Depoi et al., 2008; Levandowski and Kalkreuth, 2009; Fungaro et al., 2013; Kalkreuth et al., 2014). Disposing large amounts of fly ash into landfills can cause leaching of these heavy metals to the water through the soil and may threaten the aquatic life and environment as well as human health (Munawer, 2018).

The properties of coal fly ash are strongly dependent on the geological origin and combustion process of the coal. Therefore, it is important to characterize regional coal ash in detail to evaluatethe environmental impacts of disposal (ash leaching) (Castro, 2013).

Some studies demonstrated the toxicity of coal fly ash leachates toward aquatic or terrestrial microorganisms

*Corresponding author: Kelme Cardoso damasceno; e-mail: kelmecardoso@gmail.com 
(Tsiridis et al., 2006; 2012). Considering that there is a lack of information about correlation between chemical composition of the eluates from coal fly ash and toxicity effects toward test organisms, it is important to use different species from distinct levels of the food chain for an overall evaluation of the environmental impact of fly ashes disposal.

The aquatic toxicity of chemical substances is evaluated by ecotoxicological assaysusingrepresentative organisms of the water column or sediments. The toxicity knowledge of these substances to different aquatic organisms allows to verify the temporary impact that pollutants can cause to biota in water bodies, besides the determination of trigger valuesfor several chemical substances in order to protect the aquatic biota (Zagatto and Bertoletti, 2006).

The in vitro assayby neutral red uptake method can determine the basal cytotoxicity due to the alterations and cellular death caused by a substance (AndrighettiFröhner, 2003).Mammalian cell lines are used to monitor landfill leachate because of their high sensitivity to many environmental toxicants when compared to other bioassays (Ghosh, 2015). Considering the lack of information about environmental hazard of coal fly ash, our study aimed to assess both leaching and leachate toxicity of ash samples collected from coal-fired power plant located in the Southern of Brazil.

\section{MATERIALS AND METHODS}

\section{Materials}

All the reagents used for experimental studies were of analytical grade. The sample of coal fly ash (CM) was collected from bag filter of the Figueira coal-fired power plant, located in Paraná State, Brazil. The sample was characterized about the chemical composition and the leachate obtained on a leaching assay was submitted to in vitro cytotoxicity and in vivo ecotoxicity assays.

\section{Characterization of material}

The semi-quantitative chemical composition of the fly ash was determined by a X-ray fluorescence equipment (Bruker - Model S8 Tiger X-ray Fluorescence Spectrometer). Mineralogical composition was determined by X-ray diffractometry (Rigaku - Multiflex X-ray Diffractometer) using $\mathrm{Cu} \mathrm{K} \alpha$ radiation at $40 \mathrm{kV}$ and $20 \mathrm{~mA}$. The scan rate was $0.02^{\circ} / \mathrm{s}$ and ranged between $5-90^{\circ}(2 \theta)$. Crystalline phases identification was made by using Search-Match computer program and by searching the powder diffraction file database from International Centre for Diffraction Data (ICDD).

\section{Leaching Tests}

The leaching of the elements present in the raw fly ash was carried out using the standard Toxicity Characteristic Leaching Procedure, TCLP 1311 (USEPA, 1992). The application of the standard TCLP took place in a rotary agitator using a sample agitation at $30 \mathrm{rpm} \pm 2 \mathrm{rpm}$, under a liquid to solid ratio of $20 \mathrm{~L} / \mathrm{kg}$ at temperature of $23 \pm 2{ }^{\circ} \mathrm{C}$. An acetic acid solution at $\mathrm{pH} 2.88 \pm 0.05$ was used to prepare the extraction fluid, by diluting $5.7 \mathrm{~mL}$ of glacial acetic acid in deionized water to a volume of $1 \mathrm{~L}$. Extraction experiments included the addition of $12.5 \mathrm{~g}$ of solid sample in a polyethylene bottle followed by the addition of $250 \mathrm{~mL}$ of extraction fluid. The mixture was then agitated for $18 \mathrm{~h}$ and the eluate was collected by vacuum filtration using a glass fiberfilter. The $\mathrm{pH}$ of eluate was adjusted at 7 prior to bioassays testing to avoid $\mathrm{pH}-$ induced toxic effects.

\section{Cytotoxicity index $\left(\mathrm{CI}_{50}\right)$}

The determination of cytotoxicity index $\left(\mathrm{CI}_{50}\right)$ of coal fly ash leachate was carried out according to the ISO 10993-5. This assay was performed by the neutral red uptake method. Diluted solutions of the coal fly ash leachate $(50,25,12.25$, $6.25,3.13 \%)$ in triplicate were placed in contact to NCTC clone 929 (CCIAL 020) mouse connective tissue cells adhered to the 96 wells of the cell culture microplate. The microplates were supplied by the Nucleus of Cell Culture of the Adolfo Lutz Institute. In this assay, a negative control used was the extract of $\mathrm{Al}_{2} \mathrm{O}_{3}$ in culture medium $(0.5 \mathrm{gmL}$ $\left.{ }^{1}\right)$, positive controlwas natural rubber latex (NRL) extract in

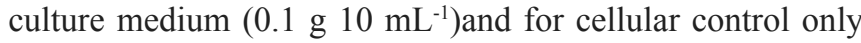
culture medium was added. Cell viability was verified by the incorporation of neutral red by the living and intact cells. The optical density was read on final test solution,using a spectrophotometer ELISA reader-SUNRISE from TECAN, at $540 \mathrm{~nm}$ and $600 \mathrm{~nm}$ as a reference filter. The percentage of cell viability was statistically calculated using the standard software installed in this spectrophotometer and the $\mathrm{CI}_{50}$ was obtained in the Origin 8.0.

\section{Acute ecotoxicity assay with Daphnia similis}

Daphniasimilisorganisms was maintained at Ecotoxicology Laboratory of Nuclear and Energy Research Institute (IPEN). Organisms were fed with an algal suspension of Pseudokirchneriella subcapitata at the concentration of $10^{5}$ cells $\mathrm{mL}^{-1}$ and a mixture of yeast and fish chow, and maintained in dilution water (MS) under controlled conditions of temperature $\left(20 \pm 2^{\circ} \mathrm{C}\right)$ and light-dark cycle (12:12hours) (ABNT, 2016a). The organism sensitivity results were in the stablished variation 2.28 to $2.69 \mathrm{mg} \mathrm{L}^{-1}$.

Neonates from 6 to 24 hours wereexposed to coal ash leachate in different concentrations $(50.0 ; 25.0 ; 12.5 ; 6.0$; $3.0 ; 1.5 \%$ ) with 20 organisms distributed in 4 tubes per concentration, for a period of 48 hours. The control was ofdilution water (MS medium). The endpoint to determine acute toxicity wasthe immobility of each organism, according to ABNT NBR12713. At the end of assay based on the number of immobile organisms as a function of concentration, $\mathrm{EC}_{50}$ was calculated using Trimmed Spearman-Karber software (Hamilton, 1977). 


\section{Acute ecotoxicity assay with Danio rerio(zebrafish)}

Danio rerio cultures are maintained in Laboratory of Applied Toxinology (LETA) at Butantan Institute, under controlled temperature conditions $\left(25 \pm 2^{\circ} \mathrm{C}\right)$ and light and dark cycle.Adult males and females are kept separate and fed twice daily with fish feed and Artemia spp. Breeders between 6-24 months of age (ABNT, 2016c) are placed in small aquaria, suitable for breeding, in the ratio of two males to one female.After spawning the eggs were collected from the aquaria and transported to the Ecotoxicology Laboratory at IPEN.The assay was carried out based on OECD No. 236 Guideline on Fish Embryo Acute Toxicity (FET) Test (OECD, 2013). Eggs collection attended the validation criteria for fertilization rate $(\geq 80 \%)$ and development stage up to 4 hours post fertilization (hpf). In 24-well plate, were distributed 1 egg per well at control intern, and 2 eggs per well with $2 \mathrm{~mL}$ of test solutions. Statistical analyze was performed using Trimmed Spearman-Karber (Hamilton, 1977) for $\mathrm{LC}_{50}$ of coal fly ash leachate to zebrafish embryos. In order to guarantee the quality of the obtained results, the test organism sensitivity was evaluated with zinc chloride $\left(\mathrm{ZnCl}_{2}\right)$ and the result was according to the limits established.Effects were observed in an inverted microscope Olympus CK40. The lethality of the individuals was identified through: lack of heartbeat, nondetachment of the tail, lack of somite formation and coagulated embryos. The leachate concentrationswere: $3.13 \%, 6.25 \%$, $12.5 \%, 25 \%$ and $50 \%$, based on the result of $\mathrm{CI}_{50}$ concentration.

\section{RESULTS}

\section{Chemical Composition}

The chemical composition of the ash (\% weight) is given in Table 1. The content of material consists of silica $\left(\mathrm{SiO}_{2}\right)$, alumina $\left(\mathrm{Al}_{2} \mathrm{O}_{3}\right)$, ferrous oxide $\left(\mathrm{Fe}_{2} \mathrm{O}_{3}\right)$, potassium oxide $\left(\mathrm{K}_{2} \mathrm{O}\right)$ and calcium oxide $(\mathrm{CaO})$ as major constituents. Quantities below $2 \%$ are also observed.

Table 1 - Chemical composition of fly ash sample.

\begin{tabular}{lccc}
\hline Oxides & $\mathrm{wt} \%$ & Oxides & $\mathrm{wt} \%$ \\
\hline $\mathrm{SiO}_{2}$ & 49.2 & $\mathrm{Cr}_{2} \mathrm{O}_{3}$ & 0.048 \\
$\mathrm{Al}_{2} \mathrm{O}_{3}$ & 21.6 & $\mathrm{PbO}$ & 0.049 \\
$\mathrm{Fe}_{2} \mathrm{O}_{3}$ & 9.86 & $\mathrm{As}_{2} \mathrm{O}_{3}$ & 0.16 \\
$\mathrm{CaO}$ & 2.06 & $\mathrm{ZrO}_{2}$ & 0.099 \\
$\mathrm{~K}_{2} \mathrm{O}$ & 2.74 & $\mathrm{Rb}_{2} \mathrm{O}$ & 0.014 \\
$\mathrm{SO}_{3}$ & 1.65 & $\mathrm{SrO}$ & 0.029 \\
$\mathrm{TiO}_{2}$ & 1.20 & $\mathrm{NiO}$ & 0.011 \\
$\mathrm{MgO}$ & 1.02 & $\mathrm{CuO}$ & 0.022 \\
$\mathrm{Na} \mathrm{O}_{2} \mathrm{O}$ & 1.23 & $\mathrm{Y}_{2} \mathrm{O}_{3}$ & 0.028 \\
$\mathrm{ZnO}$ & 0.682 & $\mathrm{~V}_{2} \mathrm{O}_{3}$ & 0.082 \\
$\mathrm{MnO}$ & 0.061 & $\mathrm{MoO}_{3}$ & 0.03 \\
$\mathrm{P}_{2} \mathrm{O}_{5}$ & 0.097 & $\mathrm{BaO}_{5}$ & $<0.001$ \\
\hline
\end{tabular}

\section{Mineralogical composition}

Crystalline phases identified for the fly ash sample are shown in Fig. 1. Ash sample is composed mainly of quartz, mullite and magnetite (which are also confirmed from their chemical compositions - Table 1). These crystalline phases are typically encountered in this type of material and were identified in other studies (Umaña-Peña, 2002; Jha et al., 2008; Lee et al., 2010; Ibanez et al., 2012; Fungaro et al.,2013; Widiastuti et al., 2014). The sample presented the amorphous halo between 20 and 30 in the $2 \theta$ angular zone which corresponds to the vitreous component of ashes.

\section{Cytotoxicity assay}

With the results of cell viability in relation to coal fly ash leachate were placed in the graphic and is shown in the Fig. 2.In this graphic we could calculate the $\mathrm{CI}_{50}$ which means the concentration of the sample that provoke injure to $50 \%$ of cell population in the assay. The $\mathrm{CI}_{50}$ obtained for coal fly ash leachate was $33 \%$.

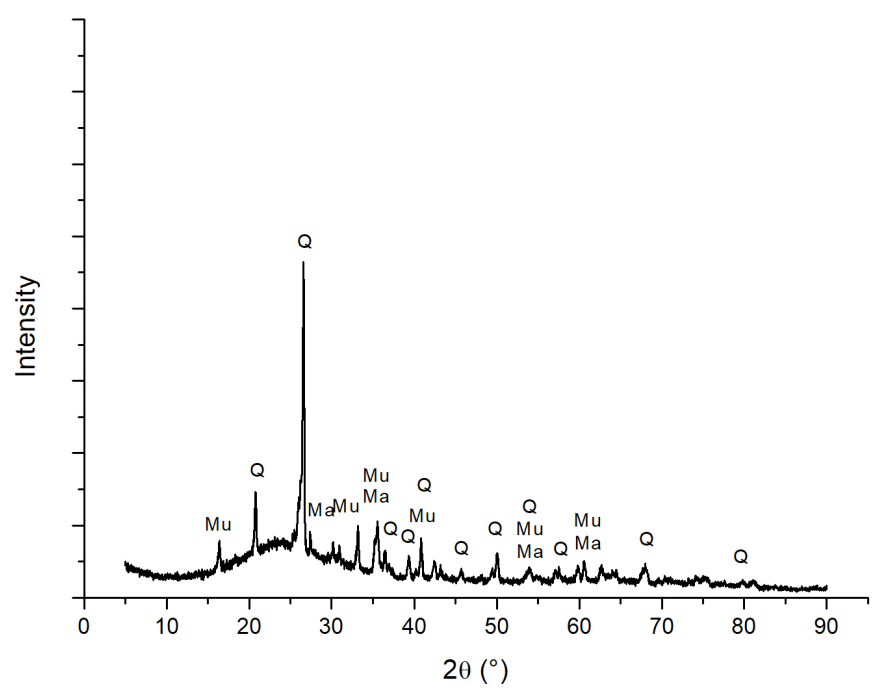

Figure 1 - XRD Patterns of ash sample: $\mathrm{Q}=$ Quartz $\left(\mathrm{SiO}_{2}\right), \mathrm{M}=$ Mullite $\left(\mathrm{Al}_{4.8} \mathrm{Si}_{1.2} \mathrm{O}_{9.6}\right)$ and $\mathrm{Ma}=$ Magnetite $\left(\mathrm{Fe}_{3} \mathrm{O}_{4}\right)$.

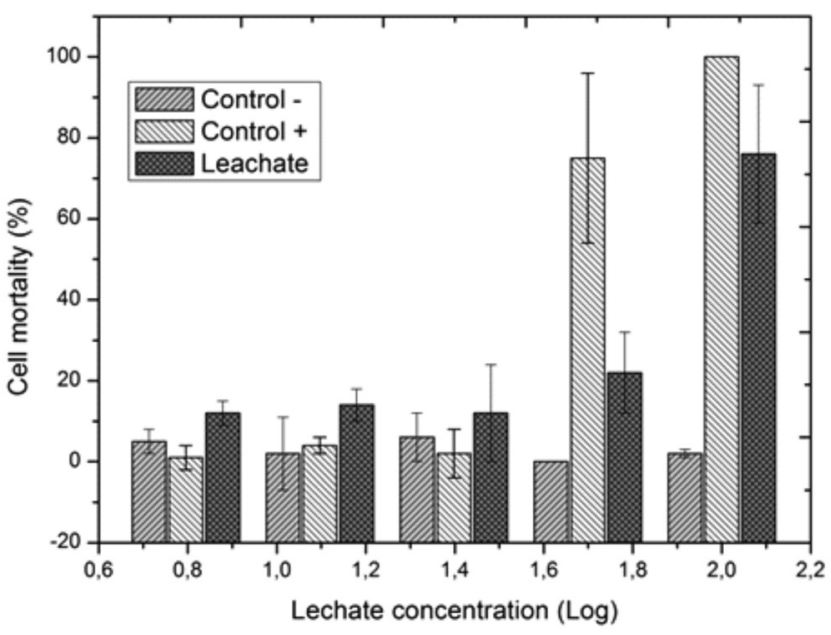

Figure 2 -Mean cell mortality in the cytotoxicity assay by neutral red uptake method.Erros bars are standard deviation. 


\section{Acute Ecotoxicity assay with Daphnia similis}

The obtained results of acute toxicityofcoal fly ash leachate on Daphnia similis are shown in Fig.3.

In the Table 2 are presented the $\mathrm{EC}_{50}$ with confidence limits of the three performed tests. The coal fly ash leachate $\mathrm{EC}_{50}$ average was $7.25 \%$.

\section{Acute Ecotoxicity assay usingDanio rerio}

The coal fly ash leachate acute ecotoxicity results on Danio rerio embryos are shown in Fig. 4 where it is observed that the mortality increased with the increasing concentration of the leachate.

The $\mathrm{LC}_{50}$ with the confidence limits results are shown in Table 3 . The coal fly ash leachate $\mathrm{LC}_{50}$ average was $4.39 \%$.

\section{DISCUSSION}

The fly ash used in this study was predominantly composed of silica and alumina $(70 \%)$ indicating that this material can be used for the synthesis of zeolite, an alternative adsorbent, for example, and, therefore, minimize environmental impacts. The characteristics and properties of fly ash samples from Brazilian power plants,

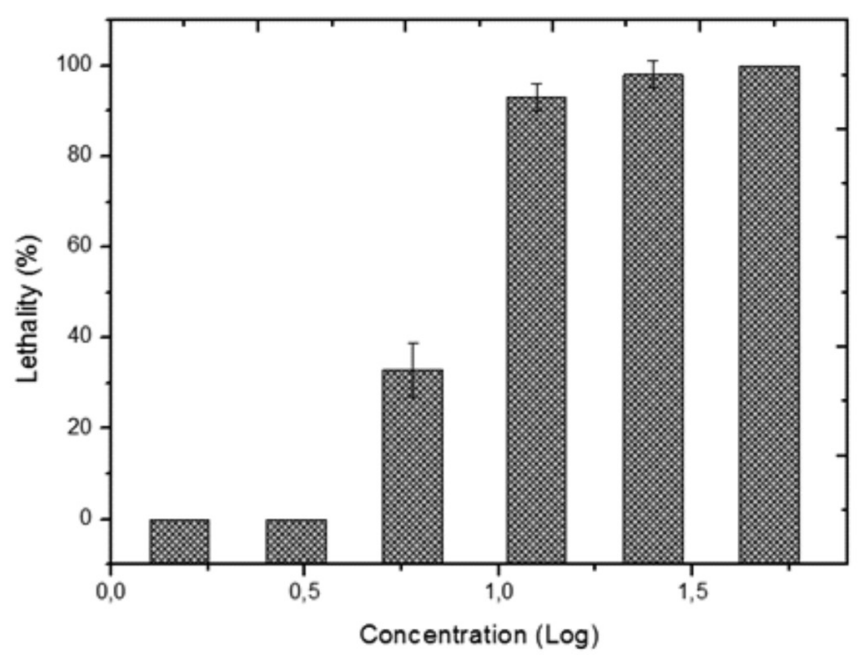

Figure 3 - Mean Daphniasimilis immobility results in relation to concentrations of coal fly ash leachate. Error bars are standard deviation.

Table 2 - Coal fly ashes leachate $\mathrm{EC}_{50}$ on Daphnia similis.

\begin{tabular}{lccc}
\hline \multirow{2}{*}{ Assay } & \multirow{2}{*}{$\mathrm{EC}_{50}(\%)$} & \multicolumn{2}{c}{ Confidence Limits } \\
\cline { 3 - 4 } & & Lower & Higher \\
\hline 1 & 7.50 & 6.29 & 8.94 \\
2 & 6.75 & 5.69 & 8.01 \\
3 & 7.51 & 6.30 & 8.94 \\
\hline Average & 7.25 & 6.09 & 8.63 \\
\hline
\end{tabular}

including Figueira coal-fired were previously discussed (Fungaro et al., 2013; Izidoro et al., 2012; Izidoro, 2013).

The procedure established by Norm NBR 10005 (ABNT NBR 10005, 2004b) was used for the classification of the ashes (Fungaro et al., 2013). The fly ash sample from Figueira coalfired power plant was considered hazardous and classified as Class I, due to As concentration was above the maximum limit allowed by Annex F of the Norm NBR 10004 (ABNT NBR 10004, 2004a).

Previous studies regarding ash samples of Brazilian coal-fired power plants reported that the concentrations of $\mathrm{As}, \mathrm{Cd}, \mathrm{Mo}, \mathrm{Pb}, \mathrm{TI}, \mathrm{U}, \mathrm{Hg}$, and $\mathrm{Zn}$ of Figueira coal-fired power plant samples are higher than others plants (Depoi et al., 2008). In other study, the major and trace elements present in coal and ashes of Figueira coal-fired power plant and their mobility were evaluated (Flues el at., 2012). The total metal and Asconcentrations in ash samples was $\mathrm{As}>\mathrm{Zn}>\mathrm{Mn}>\mathrm{Mo} \geq \mathrm{Pb}>\mathrm{Cr}>\mathrm{V}>\mathrm{Cu} \geq \mathrm{Cd}>\mathrm{Ni}>\mathrm{Co}$. Arsenic was considered the most critical element to be leached from ashes due to their high mobility $(70 \%)$ followed by Mo $(>55 \%)$ and next by $\mathrm{Mn}, \mathrm{Zn}, \mathrm{Cd}, \mathrm{Pb}(30-5 \%)$. In relation to studies on leachate elements of coal ash, the application of leaching tests and physicochemical analyses of the

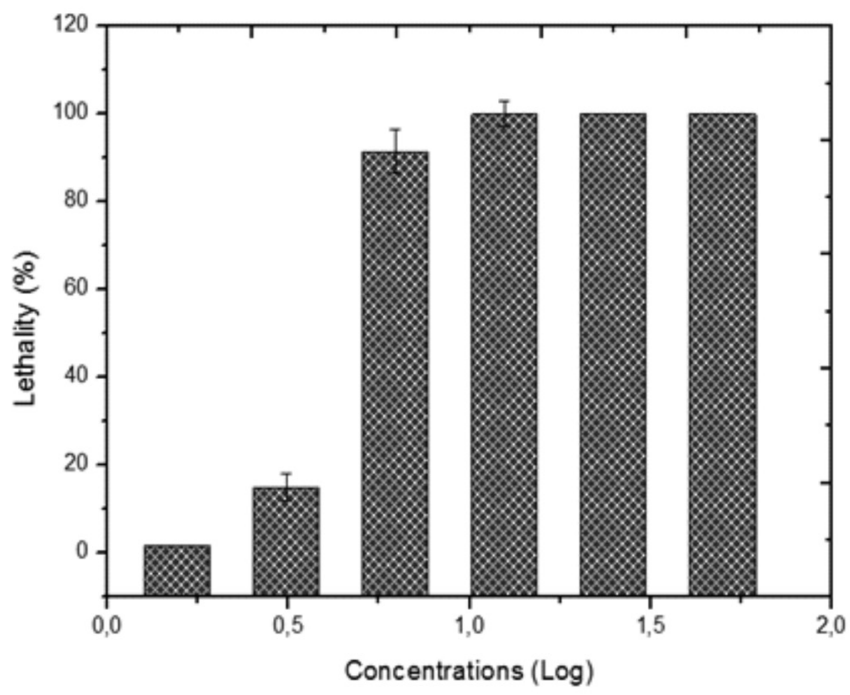

Figure 4 - Mean Danio rerio embryos lethality results in relation to concentrations of coal fly ash leachate.Error bars are standard deviation.

Table 3 - Coal fly ashes leachate $\mathrm{LC}_{50}$ on Danio rerio embryos

\begin{tabular}{lccc}
\hline \multirow{2}{*}{ Assaynumber } & \multirow{2}{*}{$\mathrm{LC}_{50}(\%)$} & \multicolumn{2}{c}{ Confidence Limits } \\
\cline { 3 - 4 } & 4.34 & 4.12 & 5.27 \\
2 & 4.54 & 4.10 & 5.03 \\
3 & 4.35 & 3.48 & 5.55 \\
\hline Average & 4.39 & 3.9 & 4.66 \\
\hline
\end{tabular}


resulting leachates is the common practice for assessment of contamination caused by its disposal or utilization. However, is difficult a comparison between various leaching procedures and ecotoxicity tests because there are several mechanisms taking place simultaneously (Tsiridis et al., 2006).

A combination of leaching tests (EN 12457-2, EN 124573 and NEN 7343), physicochemical and ecotoxicological analyses were used for the evaluation of the environmental hazard of six coal fly ashes collected from different power plants in Europe plants. Physicochemical analyses indicated that the concentration of $\mathrm{Cr}$, Mo, sulfates and total dissolved solids in the leachates of all samples exceeded the leaching limit values for inert wastes. The toxicity of leachates was evaluated using Vibrio fischeri, Brachionuscalyciflorus P. subcapitata and Daphnia magna (D. magna). The highest sensitivity was presented by D. magna and was described to the presence of $\mathrm{Cr}$, while Vibrio fischeri was the least sensitive. The toxicity of the leachates toward P. subcapitata was relatively high, but the correlation between the toxicity and heavy metals concentration was poor. The NEN 7341 leaching test was strongly suggested for the implementation of ecotoxicity characterization of these solid wastes (Tsiridis et al., 2006, 2012).

Arsenic is considered one of the most significantly toxic elements present in coal ashes. A review article emphasized the concentration of As in fly ash, leaching studies, the behavior as hazardous element on human health, environment quality and the mitigation strategies to accomplish environmental management. The concentrations in fly ash generally range from 2 to $440 \mathrm{mg} \mathrm{kg}^{-1}$, but depending on the concentration in the original coals and the combustion methods, they can be as high as $1000 \mathrm{mg} \mathrm{kg}^{-1}$ (Pandey et al., 2011).

A broad range of toxicity studies was conducted after the 2008 TVA Kingston ash spill into the Emory and Clinch rivers to evaluate potential effects of fly ash on aquatic biota. The study demonstrated that the risks to resident species were moderate and limited to locations with ash content greater than 40\% (Sherrard et al., 2015).Moreover,the Emory-Clinch system after its remediation presented low risk of excessive element exposure and limited adverse reproductive effects to freshwater turtles (Steen et al., 2015).

The in vitro toxicity assay on mammalian cells showed $\mathrm{CI}_{50}$ of $33 \%$. The presence of cytotoxic, compounds as metals can act in the lysosomal membrane stability leading to cell death, verified in the cytotoxicity assay.

In the acute toxicity assay with Daphnia similis the obtained $\mathrm{EC}_{50}$ was $7.25 \%$, probably due to the presence of arsenite $(0.16 \%)$ and this element showing a high mobility in the leaching process. The obtained result showeda higher acute toxicity when compared with the Castro (2013) results in the percolate of coal fly ash evaluation $\left(\mathrm{EC}_{50}: 25 \%\right.$ to $84 \%$ ). The difference between these results can be explained by the different types of elements extraction: in the percolate assay the soil contained in the columns could retain some toxic substances.

The fly ash sample was considered hazardous and can be classified as Class I, due to the concentration of As which was above the maximum limit allowed by Annex $\mathrm{F}$ of the Norm NBR 10004 (ABNT NBR 10004, 2004a). Arsenic was considered the most critical element to be leached from ashes due to their high mobility (70\%) followed by Mo ( $>55 \%)$ and next by $\mathrm{Mn}, \mathrm{Zn}, \mathrm{Cd}, \mathrm{Pb}(30-5 \%)$.

The $\mathrm{LC}_{50}$ results obtained for Danio rerio embryos after leachate concentrations exposure was $4.39 \%$, similar to $\mathrm{EC}_{50}$ of D. similis. Jezierska et al. (2009), described that when heavy metals are present in water, they can cause many physiological alterations in fish, the most common mechanism of toxicity is associated with enzymatic alterations in synthesis activity and lead to osmotic disturbs. Early developmental stages are more sensitive to these effects and the exposure during embryonic development can reduce the survival and hatching success. During the egg swelling there is a perivitelline space with a colloidal suspension of proteins secreted by the vitelline membrane that absorb water. The ions can enter due to the high permeability of the egg membrane, changing the chorion structure and even thepermeability (Jezierska etal., 2009).

\section{CONCLUSION}

The ash sample investigated in the present study contains considerable quantity of arsenic,being classified as hazardous waste. The leachate tested showed a high toxicity to the aquatic organisms as compared to other studies, but considering the lack of information about environmental hazard of coal fly ash, more studies has to be performed in order to assess both leaching and leachate ecotoxicity of ash samples collected from coal-fired power plant. Ecotoxicity results may be different considering the diverse characteristics on the composition of the coal fly ash, because of this, it is very important to perform more studies to characterize and understand in detail the regional coal ash hazard to the environment. More studies using different species and in vivo tests should be employed for ecotoxicological evaluations at different conditions to understand the biological response of the fly ash.

\section{REFERENCES}

ABNT (Associação Brasileira de Normas Técnicas). 2004 a. Procedimento para Obtenção de Extrato lixiviado de Resíduos Sólidos NBR. 10005. Rio de Janeiro.

ABNT (Associação Brasileira de Normas Técnicas). 2004 b. Resíduos sólidos-Classificação, v. 71, NBR 10004. Rio de Janeiro.

ABNT (Associação Brasileira de Normas Técnicas). 2016 a. Ecotoxicidade aquática - Toxicidade aguda - Método de ensaio com Daphniaspp (Crustacea, Cladocera) NBR 12713, Rio de Janeiro.

ABNT (Associação Brasileira de Normas Técnicas). 2016 c. Ecotoxicologia aquática - Toxicidade aguda - Método de ensaio com peixes NBR 15088, Rio de Janeiro.

ANDRIGHETTI-FRÖHNER, C. R., ANTONIO, R. V., CRECZYNSKI-PASA, T. B., BARARDI, C. R. M., \& SIMÕES, C. M.O. 2003. Cytotoxicity and potential antiviral evaluation of violacein produced by Chromobacteriumviolaceum. Memórias do Instituto Oswaldo Cruz, 98(6) 843-848p. https://dx.doi. org/10.1590/S0074-02762003000600023 
CASTRO, F. J. 2013. Avaliação ecotoxicológica dos percolados das colunas de cinza de carvão e de solos com cinza de carvão utilizando Lactuca sativa e Daphnia similis como organismos teste. PhD Thesis. Universidade de São Paulo, São Paulo.

DEPOI, F. S., POZEBON, D., KALKREUTH, W. D. 2008. Chemical characterization of feed coals and combustion-by-products from Brazilian power plants. Int. JournalCoalGeol, 76 227-236. https://doi.org/10.1016/j.coal.2008.07.013

FLUES, M., SATO, I. M., SCAPIN, M. A., COTRIM, M. E. B., \& CAMARGO, I. M. C. 2013.Toxic elements mobility in coal and ashes of Figueira coal power plant, Brazil. Fuel, 103 430-436. https://doi.org/10.1016/j.fuel.2012.09.045.

FUNGARO, D. A., IZIDORO, J. C., SANTOS, F. S.\& WANG, S. Coal fly ashes from brazilian power plants: chemical and physical properties and leaching characteristics. In: Fly Ash: Chemical Composition, Sources and Potential Environmental Impacts. Editor: Prabir Kumar Sarker; Nova Science Publishers, Inc., cap. 5, p. 59-84, 2013. http://hdl.handle.net/20.500.11937/36192

GHOSH, P., GUPTA, A., \& THAKUR, I. S. 2015. Combined chemical and toxicological evaluation of leachate from municipal solid waste landfill sites of Delhi, India. Environmental Science and Pollution Research, 22(12) 9148-9158. https://doi. org/10.1007/s11356-015-4077-7.

HAMILTON, M. A., RUSSO, R. C., \& THURSTON, R. V.1977. Trimmed Spearman-Karber method for estimating median lethal concentrations in toxicity bioassays. Environmental Science \& Technology, 11(7) 714-719.

IBÁÑEZ, J., FONT, O., MORENO, N., ELVIRA, J. J., ALVAREZ, S., \& QUEROL, X. 2012. Quantitative Rietiveld analysis of the crystalline and amorphous phases in coal fly ashes. Fuel. 06.090, http:// dx.doi.org/10.1016/j

ISO (International Organization for Standardization). 2009. Biological evaluation of medical devices-Part 5: Tests for in vitro cytotoxicity, Switzerland, 10 993-5.

IZIDORO, J. C. 2013. Síntese e caracterização de zeólita pura obtida a partir de cinzas volantes de carvão. $\mathrm{PhD}$ Thesis. Instituto de Pesquisas Energéticas e Nucleares, São Paulo.

IZIDORO, J. D. C., FUNGARO, D. A., DOS SANTOS, F. S., \& WANG, S. 2012. Characteristics of Brazilian coal fly ashes and their synthesized zeolites. Fuel Proc. Tech., 97 38-44. https://doi. org/10.1016/j.fuproc.2012.01.009.

JEZIERSKA, B., LUGOWSKA, K., \& WITESKA, M. 2009. The effects of heavy metals on embryonic development of fish (a review). Fishphysiologyandbiochemistry, 35(4) 625-640. https://doi.org/10.1007/s10695-008-9284-4 JHA, V. K., MATSUDA, M., \& MIYAKE, M..2008. Resource recovery from coal fly ash waste: an overview study. Journal of the Ceramic Society of Japan, 116(2) 167-175. https://doi. org/10.2109/jcersj2.116.167

KALKREUTH, W., LEVANDOWSKI, J., DELGADO, T., SCHEFFER, R., MAIA, S. M., PERALBA, M. C. R., \& BARRIONUEVO, S. 2014.Evaluation of environmental impacts of Figueira coal-fired power plant, Paraná, Brazil. Energy Exploration \& Exploitation, 32(3) 423-469. https://doi. org/10.1260/0144-5987.32.3.423

LEE, K. M. \& JO, Y. M. Synthesis of zeolite from waste fly ash for adsorption of CO2, J. Mater. Cycles. 2010. Wast. Manag, 12 212-219. https://doi.org/10.1007/s10163-010-0290-0

LEVANDOWSKI, J; KALKREUTH, W. 2009. Chemical and petrographical characterization of feed coal, fly ash and botton ash from the Figueira Power Plant, Paraná,Brazil. Int. Journal Coal Geol, 77 269-281. https://doi.org/10.1016/j.coal.2008.05.005

MUNAWER, M. 2018. Human health and environmental impacts of coal combustion. Journal of Sustainable Mining, 17(2) 87-96. https://doi.org/10.1016/j.jsm.2017.12.007

OECD (Organization for Economic Co-operation and Development). 2013. Guideline for the testing of chemicals. Fish embryo acute toxicity (FET) test $\mathrm{N}^{\mathrm{o}} 236$, Paris.

PANDEY, V. C., SINGH, J. S., SINGH, R. P., SINGH, N., \& YUNUS, M. 2011. Arsenic hazards in coal fly ash and its fate in Indian scenario. Resources, Conservation and Recycling, 55(910) 819-835, https://doi.org/10.1016/j.resconrec.2011.04.005

SHERRARD, R. M., CARRIKER, N. E. \& GREELEY JR., M. S. 2015. How toxic is coal ash? A laboratory toxicity case study. Integrated Assessment and Management, 11(1) 5-9. https://doi. org/ 10.1002/ieam.1587

STEEN D. A., VAN DYKE J. U., JACKSON, B. P. \& HOPKINS, W.A. 2015. Reproduction and hatchling performance in freshwater turtles associated with a remediated coal fly-ash spill. Environmental Research, 138 38-48. https://doi.org/10.1016/j. envres.2015.01.024.

TSIRIDIS, V., PETALA, M., SAMARAS, P., KUNGOLOS, A. \& SAKELLAROPOULOS, G.P., 2012. Environmental hazard assessment of coal fly ashes using leaching and ecotoxicity tests. Ecotoxicology and Environmental Safety, 84 212-220. http:// dx.doi.org/10.1016/j.ecoenv.2012.07.011

TSIRIDIS, V., SAMARAS, P., KUNGOLOS, A. \& SAKELLAROPOULOS, G. P.2006. Application of leaching tests for toxicity evaluation of coal fly ash. Environmental Toxicology: An International Journal, 21(4) 409-416, https://doi.org/10.1002/tox.20187. UMAÑA-PEÑA, J. C. 2002. Síntesis de zeolitas a partir de cenizas volantes de centrales termoeléctricas de carbón. $\mathrm{PhD}$ Thesis. Universitat Politécnica de Catalunya, Barcelona, Espanha.

USEPA (Environmental ProtectionAgency). 1992. SW 864 Method 131. Test method for evaluating solid waste, physical/chemical methods - toxicity characterization leaching procedure (TCLP). Washington, U.S.A.

WIDIASTUTI, N., HIDAYAH, M. Z. N., PRASEYTOKO, D., \& FANSURI, H. 2014. Synthesis of zeolite X-carbon from coal bottom ash for hydrogen storage material. Adv. Mat. Lett, 5 (8) 453-458. http://doi.org/10.5185/amlett.2014.amwc1019

ZAGATTO, P. A., BERTOLETTI, E. 2006. Ecotoxicologia aquática - princípios e aplicações. São Carlos: Rima 478 p. 